\title{
Anthós
}

9-2015

\section{The Storyteller's Trance in the Turn of the Screw}

Leslie C. Slape

Portland State University

Follow this and additional works at: https://pdxscholar.library.pdx.edu/anthos

Part of the Literature in English, North America Commons

Let us know how access to this document benefits you.

\section{Recommended Citation}

Slape, Leslie C. (2015) "The Storyteller's Trance in the Turn of the Screw," Anthós: Vol. 7: Iss. 1, Article 7. https://doi.org/10.15760/anthos.2015.55

This open access Article is distributed under the terms of the Creative Commons Attribution-NonCommercialShareAlike 4.0 International License (CC BY-NC-SA 4.0). All documents in PDXScholar should meet accessibility standards. If we can make this document more accessible to you, contact our team. 


\title{
The Storyteller's Trance in The Turn of the Screw
}

\author{
Leslie C. Slape
}

Since the publication of The Turn of the Screw in 1898, critics have scrutinized Henry James's novella from myriad angles in their attempts to untangle its ambiguity. One area that has drawn critical attention is the prologue, in which an unnamed narrator tells of a long-ago Christmas in a country house where he heard a friend, Douglas, read a chilling story handwritten by a governess about two children possessed by ghosts. This prologue, which sets up the main tale, initially seems to be framing the story-a structure which may be familiar to readers of One Thousand and One Nights, Boccaccio's Decameron, or Chaucer's Canterbury Tales. But in those collections, the frame returns after each tale concludes; in Turn of the Screw, the frame does not return. Examining Turn of the Screw from the perspective of - and through my own experience as-a storyteller, I argue that the actions of both the prologue, the main tale, and the governess herself are driven by the storyteller's trance, a state of altered consciousness experienced by both storyteller and listeners (Crago), and that this trance is the reason the frame does not close the book.

In his preface to the 1908 New York edition of Turn of the Screw, Henry James describes the story as "a fairy tale pure and simple," acquiring the essence of his story- "some dead servants and some children" - orally from a friend, who in turn had heard it from a friend (Jones 8). When examined as a fairy tale, several fairy tale motifs become evident: a journey from home (the governess's journey from Hampshire to Bly), a mysterious promise (her employer's exhortation that she "never, never" contact him (6)), a beautiful appearance signifying goodness (the children, Flora and Miles), a hideous appearance signifying evil (the ghosts, Quint, and Miss Jessel), a 
hero’s helper (the housekeeper, Mrs. Grose), and a heroic quest (the governess's fight to save the children from the ghosts) (Propp). Everything within a fairy tale is either wholly good or wholly bad, and in Turn of the Screw, the governess sees herself as the good heroine and the ghosts as purely evil. The mansion that the governess oversees bears a literary resemblance to Bluebeard's castle (Lang), a story with which James was familiar and mentioned in the 1908 preface. James devotes the prologue to the storytelling etiquette of provenance, "where the story comes from," and sets the telling for Christmas, which in the Victorian era was traditionally a time to tell ghost stories (Jerome). Significantly, he surrounds his middle narrator, Douglas, with a group of listeners eager to enter the storyteller's trance.

In stating the provenance, the unnamed narrator tells the reader that the story came from a friend, Douglas, who got it from his friend, a governess. This type of provenance is common to ghost stories and urban legends, and boils down to "this happened to a friend of a friend" or "FOAF." FOAF-tales are generally presented as if they are true, even though listeners know the mediation suggests an unreliable narrator. Although Douglas never uses the word "true" in connection with the tale, he says the events happened to the governess, who "sent me the papers in question before she died" (James, Turn of the Screw 2 ). She also told it to him orally (3). His audience never asks if the story is true; they appear to be more excited that they are the first audience to hear it, and that it has two "turns" of the screw (1), meaning they want to hear something scarier than the story they just heard. This condition Douglas promises to fulfill, describing the tale as beyond any other in "general uncanny ugliness and horror and pain” (2). The listeners “can’t wait for the story!” (3). The narrator assures the reader that he made "an exact transcript" of the governess's manuscript (4). He is making sure the reader knows that the story belongs one hundred percent to her, without alteration by any other storyteller. Once Douglas begins to read, the governess takes over from him as narrator and the storyteller's trance takes effect on him, his listeners, and the reader as well.

A storyteller's trance occurs when a story takes complete possession of a storyteller and listeners. When the trance is in full effect, everyone's breathing slows, causing a hush to fall upon the 
room. Everything falls away except the story. The teller and listeners merge with the events and characters, imagination takes control, and everything the characters experience feels real. Several indications within the novella imply that the people at the house party knew about and welcomed the trance effect. The first words of the book are, "The story had held us, round the fire, sufficiently breathless," the adverb indicating that the group wanted to be held breathless. When they say, "we want to hear about them" later on the same page, they mean they wanted to experience a higher level of breathlessness (or a more intense trance) through another "turn of the screw." The trance first affected Douglas when the governess told him the story and made him shiver on a hot day: "I remember the time and the place-the corner of the lawn, the shade of the great beeches and the long, hot summer afternoon. It wasn't a scene for a shudder, but oh-!” (2-3). In other words, this story casts such a powerful spell it does not even require a dark winter night and a fireside to give someone the willies! The tale has possessed Douglas ever since, for earlier he says he took the tale into his heart and "never lost it" (2). The unnamed narrator-who is part of the "compact and select" group that has gathered around the hearth-describes the listeners as "our hushed little circle" and "subject to a common thrill" (4). Both the "hush" and the "common thrill” are indicative of the storyteller's trance. As Douglas begins to read, his voice changes, and he imagines the governess: "Douglas...had begun to read with a fine clearness that was like a rendering to the ear of the beauty of his author's hand” (6). He has entered the trance.

Could the governess have entered a similar trance unaware when she came to Bly and imagined herself inside a fairy tale (9)? Is her narrative the chronicle of an intense storyteller's trance? She says herself that she has an active imagination. When she sees the great country mansion at Bly where she is to care for the two children, Flora and Miles, she is pleasantly surprised that it is not a melancholy place (7). Her room is "impressive, one of the best in the house," with full-length mirrors (7). Flora takes her on a tour of the rambling structure with its empty rooms, crooked staircases, and two crenellated towers (9). The governess feels as though she has stepped into a fairy tale: 
I had the view of a castle of romance inhabited by a rosy sprite, such a place as would somehow, for diversion of the young idea, take all color out of storybooks and fairytales. Wasn't it just a storybook over which I had fallen adoze and adream? (9)

That the governess fantasizes herself a storybook heroine when she thought she heard "a sound or two, less natural and not without, but within..." (8). Although these sounds could be coming from the servants, her imagination creates a villain for her fairy tale. She sees her first ghost, Quint, in the crenelated tower (14-15), and soon after she sees him again, sights that give a "turn of the screw" to her rosy fantasy and overlay it with danger (20). A female ghost, Miss Jessel, appears at the lake (28), and both ghosts appear on the crooked staircases (29-30 and 42). James likens Quint and Miss Jessel to goblins or evil fairies rather than ghosts ("Preface"), and in older European fairy tales such ancient creatures steal children, often substituting a look-alike changeling. When the governess says of Flora, "She's not alone, and at such times she's not a child; she's an old, old woman” (79), she refers to Flora either as a changeling or possessed by Miss Jessel's spirit. One way to exorcise a changeling is to make it admit its identity aloud, a dangerous challenge seen in several Scottish, Irish, and Scandinavian folktales. But the governess holds back from summoning the ghosts:

I always broke down in the monstrous utterance of names. As they died away on my lips, I said to myself that I should indeed help them to represent something infamous, if, by pronouncing them, I should violate as rare a little case of instinctive delicacy as any schoolroom, probably, had ever known. (51-52)

The storyteller's trance begins to take hold of the governess early, when she fantasizes about the handsome master in Harley Street. In her fantasy, he appears as the charming prince who will show up one day and marry her. She does not realize that she has miscast him, and that his function in her fairy tale is actually that of the donor (Propp), who prepares the way for the heroine to meet the 
helper, Mrs. Grose. While daydreaming of the master, imagining herself meeting him by chance in the garden, she slips into the trance and sees the ghost of Quint in the tower. She describes an eerie absence of sound like that of the audience's hush during a storytelling:

The place, moreover, in the strangest way in the world, had, on the instant, and by the very fact of its appearance, become solitude. To me at least, making my statement here with a deliberation with which I have never made it, the whole feeling of the moment returns. It was as if, while I took inwhat I did take in - all the rest of the scene had been stricken with death. I can hear again, as I write, the intense hush in which the sounds of evening dropped. The rooks stopped cawing in the golden sky, and the friendly hour lost, for the minute, all its voice. (James, Turn of the Screw 16)

This passage further indicates that the group of listeners is in the storyteller's trance. That the governess is in the trance, mesmerized by the story she is living out, is evident by the "prodigious palpable hushes" she frequently experiences and associates with the appearance of the ghosts (52). The governess experiences the "hushes" whenever she believes the ghosts of Quint or Miss Jessel are nearby, describing it as "a pause of all life" (16). The statement, "I can hear again, as I write, the intense hush...," indicates how easily her imagination pulls her into the trance state.

But the governess is no ordinary storyteller, most of whom slip easily back to reality once finishing a story. She wants to be carried away from what must seem a tremendously dull existence after the lively home and village life that she diverts the children within Chapter 13. On a susceptible personality, the temptation of the trance effect lies in its ability to render the person floating about in a state of imagination. The eternal question of Turn of the Screw has been: Does the governess imagine the ghosts, or are they real? The answer could very likely be both. The governess's transformation of Bly from a country home to a fairy tale castle to a house of horrors began purely as imaginary play, but in the fairy tale genre that James draws from, if one tries hard enough to enter the realm of the faerie, sooner 
or later success will come. And as many a tale proves, you should be careful what you wish for.

When the governess is in a dreamy, suggestive mood, sights and sounds in the outside world (if noticed at all) become part of her story, just as they do when a storyteller holds the listeners spellbound. When the governess is in such a mood and sees something, usually in imperfect light, she always interprets it as an apparition, even though it could be a trick of the light. As I previously mentioned, she falls into a daydream (the trance), and then sees Quint in the tower (15). After a rain, she thinks of past events rather than the current moment, and then sees Quint outside the window (19). She plays a role in Flora's game and sees Miss Jessel by the lake (29). She reads a novel and sees Quint on a darkened stair (3). In a nighttime ghost hunt for Quint, she sees Miss Jessel on the stair (42). After this point, she constantly looks for ghosts, and might be in a continuous state of trance-or as she describes it, "my endless obsession” (61).

The book ends with the death of Miles as the governess is trying to exorcise Quint. She holds the boy until he is breathless, a grim echo of the first line of the book. But why does the frame not reappear at the end of this story? Why does the unnamed narrator fail to reappear and wrap things up? One reason lies in the idea of provenance. If one thinks of the opening not as a frame, but simply as an elaborate way of saying "this happened to a friend of a friend," then the narrator is not obligated to restate it at the end. Storytellers generally state provenance at the beginning or end of a story, but not both. But there is another, eerier reason that the frame does not close the book. We know from the prologue that the governess obtained another position, which should have been impossible if she drove a child to hysterics and caused the death of another. Douglas does not explain how she got a job with his family. The governess could have written an epilogue to explain, but she does not, though it is very likely that she has a gap in her memory. As a result of leaving the governess in a state of altered consciousness at the end of the book, James does not allow her to come back to herself or to be aware of anything that followed-and there are many possibilities for what came next. Perhaps she went home and, to her surprise, received a kind letter from her employer telling her that he believes her story and that Flora has fully recovered. Perhaps Miles did not die after all, and is 
Douglas. In the spirit of a horror story, I prefer to think that Quint saved Miles, and in exchange laid a curse on the governess, warning her that if she would die if she told anyone what happened, and anyone who passed on the tale afterwards would also die. The reader knows that the governess did die after she passed the tale onto Douglas, and that Douglas in turn died after he passed the tale on to the unnamed narrator... who now seems to have gone missing from the narrative. Let us not forget that this tale was published in 1898, a time when people often read aloud to each other. James subliminally lets a ghost walk over to his readers' graves.

By employing the motif of the storyteller's trance in Turn of the Shrew, James allows the reader's imagination to have full sway over the storytelling process. Just as the listeners of the governess's tale, readers may sense that an oral tale has just ended upon finishing James's novella. As the effect of the storyteller's trance becomes far more powerful if allowed to linger and dissipate naturally, James ends the book with the governess alone, and everyone else-the heroine, narrators, and listeners-still in the trance. During the lingering hush, the reader closes the book.

\section{Works Cited}

Crago, Hugh. Entranced by Story: Brain, Tale and Teller, from Infancy to Old Age. New York: Routledge, 2014. Kindle file.

"FOAF." Oxford English Dictionary. Web.

James, Henry. "Preface to Volume 12 of the New York Edition." The Ladder. Adrian Dover, 20 Apr. 2009. Web. 3 Dec. 2014.

http://www.henryjames.org.uk/prefaces/home.htm

---. The Turn of the Screw. Ed. Stanley Applebaum. New York: Dover, 1991. Print. Jerome, Jerome K. Told After Supper. London: Leadenhall, 1891. EPUB file.

Jones, Steven Swann. "Folklore in Jame's Fiction: Turning the Screw.” Western Folklore 60.1 (2001): 1-24. Web. 14 Apr. 2015. http://dx.doi.org/10.2307/1500193

Lang, Andrew, ed. “Bluebeard.” The Blue Fairy Book. New York: Child’s Classic, 1948. Print.

Propp, Vladimir. Morphology of the Folktale. Trans. Laurence Scott. 1968. Print.

"Provenance." Oxford English Dictionary. Web.

"Turn." Oxford English Dictionary. Web. 